\title{
Determinants of Inclusive Growth on the Inequality
}

\author{
Muhamad Kanzu Satrio ${ }^{1}$, Syamsul Amar' ${ }^{2}$ Hasdi Aimon ${ }^{3}$ \\ ${ }^{1}$ Universitas Negeri Padang, Padang, Indonesia, $\bowtie$ (e-mail) iyo.affinity@gmail.com \\ ${ }^{2}$ Universitas Negeri Padang, Padang, Indonesia, $\square$ (e-mail) syamsul_amar3@yhoo.com \\ ${ }^{3}$ Universitas Negeri Padang, Padang, Indonesia, $\bowtie$ (e-mail) s3dkpl@gmail.com
}

\begin{abstract}
This study presents an analysis of inclusive growth inequality during 2011-2016 and the influence of economic growth, health, education and government spending on infrastructure on inclusive growth inequality in West Sumatra province, Indonesia. To empirically analyze the phenomenon of economic growth inclusiveness, the Poverty-Equivalent Growth Rate (PEGR) method is used. With the PEGR method, an Inclusive Growth Index for inequality (IGin) was formed using the Gini index and 60 percent of the lowest population expenditure. The model used is the Random Effects Model panel data regression analysis. From the PEGR method, it was found that in the provincial aggregate, inclusive growth in inequality in West Sumatra still needed to be improved. Throughout the observation period the provincial aggregate only in 2014 experienced inclusive growth in inequality. Health has a positive and significant effect at the five percent significance level, while education has a positive and significant effect at the 10 percent significance level. Government expenditure on infrastructure has a negative and significant effect at the five percent significance level, while economic growth has no statistically significant effect for inclusive growth in inequality in West Sumatra in the 2011-2016 period.
\end{abstract}

Keywords: inclusive growth, inequality, PEGR

\section{Introduction}

Public welfare is the ultimate goal of development. To achieve this, development needs to pay attention to various aspects. Development should not only focus on economic growth. The impact of development that only pursues high economic growth will actually widen inequality. Facts revealed by the World Bank in Syamsul et al (2017) that growth-oriented development will cause various problems. One of the problems is the increase in inequality (ruthless growth). Economic growth must be quality growth. Quality growth will lead to inclusive growth. Inclusive means development that not only increases output but also equalizes income distribution, reduces unemployment, and alleviates poverty. Inclusive growth is defined as growth that not only creates new economic opportunities, but also guarantees equal accessibility to opportunities created for all segments of society, especially for the poor (ADB, 2012).

The economic growth of West Sumatra has continued to experience a slowdown since 2011. However, on average the economic growth of West Sumatra is still above five percent. This shows that the economy in West Sumatra is still in good condition. However, inequality in West Sumatra fluctuates every year. If seen from its development, inequality in West Sumatra in 2016 increased compared to 2011. If you see the conditions of the last 20 years, the inequality that is currently occurring has increased. The West Sumatra gini index in 1996 was only 0.28 . This indicates that the existing development has actually widened the income distribution. Meanwhile, the open unemployment rate and existing poverty percentages show a downward trend.

Rauniyar and Kanbur (2010) define inclusive growth namely growth which is accompanied by a decrease in income inequality. In their research they support plants for the poor (pro-poor growth). The results of his research are that when economic growth for poor people is lower than for rich people, inequality will increase, conversely if economic growth for poor people is higher than for rich people, then inequality will decrease. Ali \& Son (2007) define inclusive growth as a pro-poor increase in social opportunities and examine what is included in social opportunities (access to health or education) distributed based on income and how this distribution changes over time. From the two 
definitions above, the two studies assume that inclusive growth is economic growth that supports the poor. The existence of economic growth must reduce income inequality and increase access for the poor to education and health. With the increase in the quality of education and health for the poor, there is a great opportunity for them to get out of poverty.

Klasen (2010) defines inclusive growth that is when all elements of the rich to the poor participate in economic activities that lead to economic growth. Decreasing inequality in the welfare dimension is very important in supporting the economy, including education, nutritional health, and social integration. Lee \& Sissons (2016) proxy the inclusiveness of development with poverty. The results of this study indicate that economic growth does not reduce poverty. This means that the existing economic growth is not pro-poor growth. Economic growth is not pro-poor. This will cause higher inequality.

From the current phenomenon, the construction that took place in West Sumatra has not been known whether it has led to inclusive growth inequality or not. A measure is needed to determine the inclusiveness of West Sumatra simultaneously. Looking at the existing phenomena, it cannot be concluded whether growth in West Sumatra has been inclusive or not. To find out that it is necessary to have an indicator to see whether the growth that took place in West Sumatra is an inclusive plant or not. In addition, it is important to study further to find out what are the factors that determine inclusive growth in inequality in West Sumatra.

\section{Methods}

This research is a literature study by analyzing secondary data. Spatial coverage of studies is all districts / cities in West Sumatra, which number 19 districts / cities. The year data series used are from 2011 to 2016 with a total of 114 observation units.

In this study using secondary data include: Gross Regional Domestic Product (GRDP) on the basis of constant prices, health indices, mean years school, and government spending on infrastructure. Data is taken from several publications published by the Central Sumatra Provincial Statistics Agency (BPS) and the Indonesian Directorate General of Fiscal Balance.

\section{Operational definition}

\section{Inclusive Growth on Inequality}

Inclusive growth in inequality (IGin) is in the form of an index value or coefficient of inclusive growth obtained from the results of calculating the PEGR Inclusive model. The result of this processing is an index unit.

\section{Economic growth}

Economic growth (lnGRDP) is the rate of economic growth in districts / cities $i$ in period $t$ which is in the form of the value of natural logarithms of Gross Regional Domestic Product (GRDP) on the basis of Constant Prices according to districts / cities in the period 2011-2016 (in percent).

\section{Health}

Health (HEALTH) is measured by the percentage of the population with adequate nutrition. The percentage of the population with adequate nutrition is the number of people who meet the minimum nutritional adequacy standard compared to the total population. Residents who only meet the minimum limit of 2,150 kcal / cap / day or only $57 \mathrm{gr} / \mathrm{cap}$ / day of protein are not included in the population of adequate nutrition. Data is processed from the results of the National Socio-Economic Survey (Susenas) BPS of West Sumatra Province. Through these two variables a measure will be formed, namely the percentage of the population with sufficient nutrition.

\section{Education}

To use education (EDU) the mean years school (MYS) is used. MYS is the mean years school district / city $i$ in period $t$, in the form of length of time the public is educating districts / cities in a certain period, expressed in years.

\section{Government Expenditures for Infrastructure}

The growth of government spending on infrastructure (lnINF) is the growth of the total regional expenditure of the district government $i$ in the period $t$. that is the value of the natural logarithm of 
government expenditure for infrastructure. The coverage of government expenditure for infrastructure consists of road infrastructure, irrigation, networks, buildings and buildings in the form of total expenditure originating from the Regional Budget and Expenditures. This value is expressed in percent.

\section{Poverty Equivalent Growth Rate (PEGR)}

To answer the first research objective in measuring and analyzing empirically the phenomenon of economic growth inclusiveness in districts / cities in West Sumatra, this study uses the PovertyEquivalent Growth Rate (PEGR) analysis method. The definition of inclusive growth towards inequality used in this study uses indicators of inequality approaches. The analysis model related to the phenomenon of economic growth inclusiveness used is:

$I G_{\text {in }}=\left(E_{\text {ing }} / E_{\text {in }}\right) G_{g}$

Where:

$I G_{\mathrm{In}}:$ : coefficient of inclusive growth towards inequality;

$E_{\text {in }}:$ elasticity of inequality to the percentage of 60 percent of the lowest population expenditure on total expenditure;

$E_{\text {ing }}:$ elasticity of inequality towards economic growth;

$G_{g}:$ economic growth ;

$I G_{\text {In }}$ in states the growth inclusiveness in reducing inequality, so that growth is declared inclusive if the value of $I G_{\text {in }}>G_{g}$. The values of $E_{\text {ing }}$ dan $E_{\text {in }}$ in equation (11) above are obtained in the same way in the PEGR concept. By defining inequality (in) as a function of the inequality value (z) and and the average expenditure of 60 percent of the lowest population $(x)$ written as follows:

in $=$ in $(z, x)$

Then changes in inequality in period 1 and period 2 can be calculated as:

$i n_{12}=i n_{2}-i n_{1}=\operatorname{Ln}\left[i n\left(z_{2}, x_{2}\right)\right]-\operatorname{Ln}\left[i n\left(a_{1}, x_{1}\right)\right]$

And the change in the average percentage of expenditure for the lowest 60 percent of the population can be calculated as:

$\Psi=\operatorname{Ln}\left(x_{2}\right)-\operatorname{Ln}\left(x_{1}\right)$

Thus the elasticity of inequality towards the average expenditure of 60 percent of the lowest population $\left(E_{\mathrm{in}}\right)$ can be calculated as:

$E_{\mathrm{in}}=i n_{12} / \Psi$

While changes of economic growth $G_{g}$ are calculated from Gross Regional Domestic Product (GRDP), then changes in period 1 and period 2 economic growth can be calculated as:

$G_{g}=\operatorname{Ln}\left(P D R B_{2}\right)-\operatorname{Ln}\left(P D R B_{1}\right)$

Thus, the elasticity of inequality in economic growth $E_{\text {ing }}$ can be calculate as:

$E_{\text {ing }}=i n_{12} / G_{g}$

The results of calculating equations (5) and (7) above are then included in equation (1) to obtain an inclusive growth index value to be compared with the value of $G_{g}$ economic growth.

PEGR values can be grouped as follows:

1. If $l$ Gin $=G g$ then it means growth is neutral, each person receives the same proportional benefits from growth.

2. If $I$ Gin $>G g$ means growth is pro poor growth, the poor receive more benefits from growth.

3. If $0<1$ IGin $<\mathrm{Gg}$ means growth has not been pro poor growth, the benefits of growth are more accepted by the non-poor population (increasing inequality) but poverty reduction still occurs.

4. If IGin $<0$ means growth is anti pro poor growth or the benefits of growth enjoyed by non-poor people, inequality increases. 


\section{Panel Data Regression Model}

To measure and analyze the influence of selected factors (economic growth, health, education, government spending on infrastructure) on inclusive growth in inequality (IGin) in districts / cities in West Sumatra, analysis of panel data regression equations is used. Panel data regression can be modeled as follows:

$D\left(\operatorname{lGin}_{\text {it }}\right)=a+\beta_{1} D\left(\ln G R D P_{\text {it }}\right)+\beta_{2} D\left(\right.$ HEALTH $\left._{\text {it }}\right)+\beta_{2} D\left(E D U_{\text {it }}\right)+\beta_{4} D\left(\ln l N F_{\text {it }}\right) \ldots$.

Where:

$\mathrm{i}=19$ districts / cities in West Sumatra Province

$\mathrm{t}=2011,2012,2013,2014,2015,2016$

$\alpha \quad$ : intercept (constant)

$\operatorname{IGin}_{\mathrm{i}, \mathrm{t}} \quad$ : Inclusive coefficient or index of growth for poverty, inequality, and unemployment in district / city i at time $t$

InGRDP itt : District / city economic growth (GRDP) i at time $\mathrm{t}$

HEALTH $_{\text {it: }}$ : Health in district / city i at time $\mathrm{t}$

$E D U_{i, s} \quad:$ Education in district / city i at time $\mathrm{t}$

lnINF $F_{\text {i,t }} \quad$ : Growth in government expenditure for district / city infra structure $i$ at time t

$\beta_{1,2: 4,4} \quad$ : Regression coefficients of factors $1,2,3$, and 4

\section{Results and Discussion}

\section{Inclusivity of Economic Growth on Inequality}

Reducing of inequality is one measure for economic growth to be called inclusive growth. IGin shows the inclusiveness of economic growth in reducing inequality. Growth is to be inclusive if the coefficient of growth inclusiveness towards inequality (IGin) has a greater value than economic growth $(\mathrm{Gg})$. The coefficient of inclusiveness of growth with respect to inequality (IGin) is shown in Table 1 below.

Table 1 Inclusive and Non-Inclusive Category for Inequality of Regency / City of West Sumatra Province in 2011-2016

\begin{tabular}{|c|c|c|c|c|c|c|}
\hline \multirow{2}{*}{ Region } & \multicolumn{6}{|c|}{ Inclusive growth towards inequality (IGin) } \\
\hline & 2011 & 2012 & 2013 & 2014 & 2015 & 2016 \\
\hline Kepulauan Mentawai & $\begin{array}{c}\text { Not } \\
\text { Inclusive }\end{array}$ & $\begin{array}{c}\text { Not } \\
\text { Inclusive }\end{array}$ & $\begin{array}{c}\text { Not } \\
\text { Inclusive }\end{array}$ & Inclusive & $\begin{array}{c}\text { Not } \\
\text { Inclusive }\end{array}$ & $\begin{array}{c}\text { Not } \\
\text { Inclusive }\end{array}$ \\
\hline Pesisir Selatan & $\begin{array}{c}\text { Not } \\
\text { Inclusive }\end{array}$ & $\begin{array}{c}\text { Not } \\
\text { Inclusive }\end{array}$ & $\begin{array}{c}\text { Not } \\
\text { Inclusive }\end{array}$ & $\begin{array}{c}\text { Not } \\
\text { Inclusive }\end{array}$ & Inclusive & $\begin{array}{c}\text { Not } \\
\text { Inclusive }\end{array}$ \\
\hline Kab. Solok & $\begin{array}{c}\text { Not } \\
\text { Inclusive }\end{array}$ & $\begin{array}{c}\text { Not } \\
\text { Inclusive }\end{array}$ & Inclusive & Inclusive & $\begin{array}{c}\text { Not } \\
\text { Inclusive }\end{array}$ & $\begin{array}{c}\text { Not } \\
\text { Inclusive }\end{array}$ \\
\hline Sijunjung & $\begin{array}{c}\text { Not } \\
\text { Inclusive }\end{array}$ & $\begin{array}{c}\text { Not } \\
\text { Inclusive }\end{array}$ & $\begin{array}{c}\text { Not } \\
\text { Inclusive }\end{array}$ & $\begin{array}{c}\text { Not } \\
\text { Inclusive }\end{array}$ & $\begin{array}{c}\text { Not } \\
\text { Inclusive }\end{array}$ & $\begin{array}{c}\text { Not } \\
\text { Inclusive }\end{array}$ \\
\hline Tanah Datar & $\begin{array}{c}\text { Not } \\
\text { Inclusive }\end{array}$ & $\begin{array}{c}\text { Not } \\
\text { Inclusive }\end{array}$ & $\begin{array}{c}\text { Not } \\
\text { Inclusive }\end{array}$ & Inclusive & $\begin{array}{c}\text { Not } \\
\text { Inclusive }\end{array}$ & Inclusive \\
\hline Padang Pariaman & $\begin{array}{c}\text { Not } \\
\text { Inclusive }\end{array}$ & $\begin{array}{c}\text { Not } \\
\text { Inclusive }\end{array}$ & $\begin{array}{c}\text { Not } \\
\text { Inclusive }\end{array}$ & $\begin{array}{c}\text { Not } \\
\text { Inclusive }\end{array}$ & $\begin{array}{c}\text { Not } \\
\text { Inclusive }\end{array}$ & Inclusive \\
\hline Agam & Inclusive & $\begin{array}{c}\text { Not } \\
\text { Inclusive }\end{array}$ & Inclusive & $\begin{array}{c}\text { Not } \\
\text { Inclusive }\end{array}$ & $\begin{array}{c}\text { Not } \\
\text { Inclusive }\end{array}$ & $\begin{array}{c}\text { Not } \\
\text { Inclusive }\end{array}$ \\
\hline Lima Puluh Kota & $\begin{array}{c}\text { Not } \\
\text { Inclusive }\end{array}$ & $\begin{array}{c}\text { Not } \\
\text { Inclusive }\end{array}$ & Inclusive & $\begin{array}{c}\text { Not } \\
\text { Inclusive }\end{array}$ & $\begin{array}{c}\text { Not } \\
\text { Inclusive }\end{array}$ & Inclusive \\
\hline Pasaman & $\begin{array}{c}\text { Not } \\
\text { Inclusive }\end{array}$ & $\begin{array}{c}\text { Not } \\
\text { Inclusive }\end{array}$ & $\begin{array}{c}\text { Not } \\
\text { Inclusive }\end{array}$ & $\begin{array}{c}\text { Not } \\
\text { Inclusive }\end{array}$ & $\begin{array}{c}\text { Not } \\
\text { Inclusive }\end{array}$ & $\begin{array}{c}\text { Not } \\
\text { Inclusive }\end{array}$ \\
\hline
\end{tabular}


Table Cont...

\begin{tabular}{|c|c|c|c|c|c|c|}
\hline Solok Selatan & $\begin{array}{c}\text { Not } \\
\text { Inclusive }\end{array}$ & $\begin{array}{c}\text { Not } \\
\text { Inclusive }\end{array}$ & $\begin{array}{c}\text { Not } \\
\text { Inclusive }\end{array}$ & Inclusive & $\begin{array}{c}\text { Not } \\
\text { Inclusive }\end{array}$ & $\begin{array}{c}\text { Not } \\
\text { Inclusive }\end{array}$ \\
\hline Dharmasraya & $\begin{array}{c}\text { Not } \\
\text { Inclusive }\end{array}$ & $\begin{array}{c}\text { Not } \\
\text { Inclusive }\end{array}$ & $\begin{array}{c}\text { Not } \\
\text { Inclusive }\end{array}$ & Inclusive & $\begin{array}{c}\text { Not } \\
\text { Inclusive }\end{array}$ & Inclusive \\
\hline Pasaman Barat & $\begin{array}{c}\text { Not } \\
\text { Inclusive }\end{array}$ & $\begin{array}{c}\text { Not } \\
\text { Inclusive }\end{array}$ & $\begin{array}{c}\text { Not } \\
\text { Inclusive }\end{array}$ & $\begin{array}{c}\text { Not } \\
\text { Inclusive }\end{array}$ & $\begin{array}{c}\text { Not } \\
\text { Inclusive }\end{array}$ & $\begin{array}{c}\text { Not } \\
\text { Inclusive }\end{array}$ \\
\hline Padang & Inclusive & $\begin{array}{c}\text { Not } \\
\text { Inclusive }\end{array}$ & $\begin{array}{c}\text { Not } \\
\text { Inclusive }\end{array}$ & Inclusive & $\begin{array}{c}\text { Not } \\
\text { Inclusive }\end{array}$ & $\begin{array}{c}\text { Not } \\
\text { Inclusive }\end{array}$ \\
\hline Kota Solok & $\begin{array}{c}\text { Not } \\
\text { Inclusive }\end{array}$ & $\begin{array}{c}\text { Not } \\
\text { Inclusive }\end{array}$ & $\begin{array}{c}\text { Not } \\
\text { Inclusive }\end{array}$ & Inclusive & $\begin{array}{c}\text { Not } \\
\text { Inclusive }\end{array}$ & $\begin{array}{c}\text { Not } \\
\text { Inclusive }\end{array}$ \\
\hline Sawahlunto & $\begin{array}{c}\text { Not } \\
\text { Inclusive }\end{array}$ & $\begin{array}{c}\text { Not } \\
\text { Inclusive }\end{array}$ & $\begin{array}{c}\text { Not } \\
\text { Inclusive }\end{array}$ & Inclusive & $\begin{array}{c}\text { Not } \\
\text { Inclusive }\end{array}$ & $\begin{array}{c}\text { Not } \\
\text { Inclusive }\end{array}$ \\
\hline Padang Panjang & $\begin{array}{c}\text { Not } \\
\text { Inclusive }\end{array}$ & $\begin{array}{c}\text { Not } \\
\text { Inclusive }\end{array}$ & $\begin{array}{c}\text { Not } \\
\text { Inclusive }\end{array}$ & Inclusive & $\begin{array}{c}\text { Not } \\
\text { Inclusive }\end{array}$ & $\begin{array}{c}\text { Not } \\
\text { Inclusive }\end{array}$ \\
\hline Bukittinggi & $\begin{array}{c}\text { Not } \\
\text { Inclusive }\end{array}$ & $\begin{array}{c}\text { Not } \\
\text { Inclusive }\end{array}$ & $\begin{array}{c}\text { Not } \\
\text { Inclusive }\end{array}$ & Inclusive & Inclusive & $\begin{array}{c}\text { Not } \\
\text { Inclusive }\end{array}$ \\
\hline Payakumbuh & Inclusive & $\begin{array}{c}\text { Not } \\
\text { Inclusive }\end{array}$ & $\begin{array}{c}\text { Not } \\
\text { Inclusive }\end{array}$ & Inclusive & $\begin{array}{c}\text { Not } \\
\text { Inclusive }\end{array}$ & $\begin{array}{c}\text { Not } \\
\text { Inclusive }\end{array}$ \\
\hline Pariaman & $\begin{array}{c}\text { Not } \\
\text { Inclusive }\end{array}$ & $\begin{array}{c}\text { Not } \\
\text { Inclusive }\end{array}$ & $\begin{array}{c}\text { Not } \\
\text { Inclusive }\end{array}$ & Inclusive & $\begin{array}{c}\text { Not } \\
\text { Inclusive }\end{array}$ & $\begin{array}{c}\text { Not } \\
\text { Inclusive }\end{array}$ \\
\hline SUMATERA BARAT & $\begin{array}{c}\text { Not } \\
\text { Inclusive }\end{array}$ & $\begin{array}{c}\text { Not } \\
\text { Inclusive }\end{array}$ & $\begin{array}{c}\text { Not } \\
\text { Inclusive }\end{array}$ & Inclusive & $\begin{array}{c}\text { Not } \\
\text { Inclusive }\end{array}$ & $\begin{array}{c}\text { Not } \\
\text { Inclusive }\end{array}$ \\
\hline
\end{tabular}

Source: Own calculations using data from BPS 2011-2016 data sets

In Table 1, it can be seen that in the provincial aggregate, inclusive growth in inequality in West Sumatra still needs to be improved. During the observation period, only 2014 experienced inclusive growth in inequality. If we look at each district / city, at most there are only two years of regions that experience inclusive growth in inequality. These area are Solok district, Tanah Datar district, Agam district, Lima Puluh Kota district, Dharmasraya district, Padang city, Bukittinggi city, and Payakumbuh city. Meanwhile there are three regions that have not experienced inclusive growth in inequality at all. The area is Sijunjung district, Pasaman district, and West Pasaman district.

Based on Table 1 it is known that in the provincial aggregate, inclusive growth in inequality in West Sumatra still needs to be improved. During the observation period, only 2014 experienced inclusive growth in inequality. When viewed from the coefficients (Appendix 1), only in 2014 the West Sumatra IGI was positive. This shows that in 2011 to 2016 (except for 2014), the existing economic growth actually exacerbated inequality in West Sumatra.

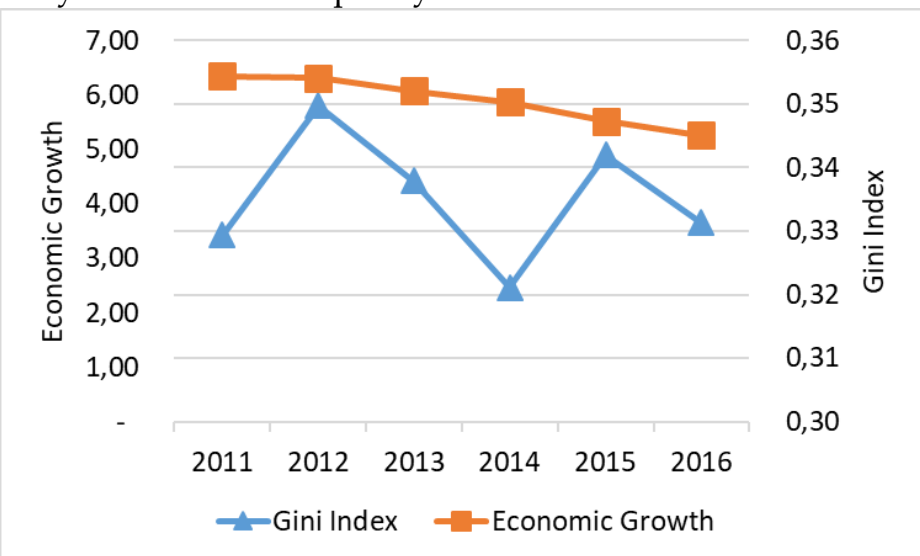

Source: Badan Pusat Statistik

Figure 1 Gini Index and Economic Growth of West Sumatra 2011-2016 
In the provincial aggregate, in West Sumatra only in 2014 did the province experience inclusive growth in inequality. If we look at existing data, it can be seen that in that year even though economic growth experienced a slowdown, inequality declined in 2014. This is supported by 60 percent share data of the population with low income to total population expenditure.

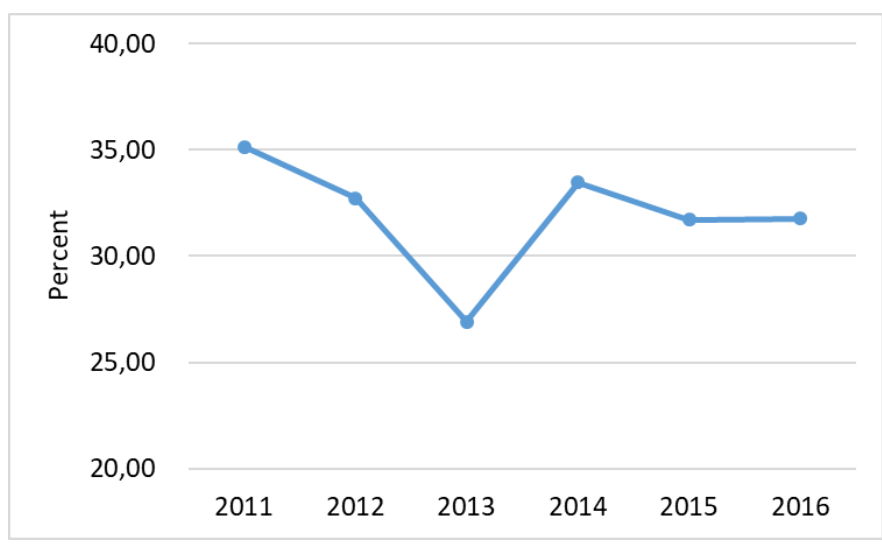

Source: Badan Pusat Statistik

Figure 2 Share 60 Percent of Population of West Sumatra 2011-2016 Lowest Income

From Figure 2, it is seen that the 60 percent share of the lowest population expenditure fluctuates every year. 2014 was the only period of inclusive growth in inequality. In that year the 60 percent share of the lowest population expenditure increased significantly compared to the previous year. This is one of the causes of inclusive growth in inequality.

From Figure 2, information is obtained that the share of income from 60 percent of the low-income population in West Sumatra fluctuates every year. 2014 was the only period of inclusive growth in inequality. In that year the share of low-income population increased significantly compared to the previous year. This is one of the causes of inclusive growth in inequality.

If viewed by district / city, there are eight regions that experienced inclusive growth in inequality by as much as two years in the study period. The area is Solok Regency, Tanah Datar District, Agam Regency, Lima Puluh Kota Regency, Dharmasraya Regency, Padang City, Bukittinggi City, and Payakumbuh City. Then there were eight regions that experienced inclusive growth in inequality by as much as one year in the study period. The area is Mentawai Islands District, South Coastal District, Padang Pariaman Regency, South Solok Regency, Solok City, Sawahlunto City, Padang Panjang City, and Pariaman City. Then there are three regions which have not experienced inclusive growth inequality in the study period. The area is Sijunjung Regency, Pasaman Regency, and West Pasaman Regency.

\section{Results of Panel Data Regression Analysis}

To answer the research question about the extent of the influence of economic growth, health, education, and government spending on infrastructure on inclusive growth which reduces inequality in districts / cities in the province of West Sumatra in 2011-2016, the authors used panel data regression analysis.

\section{Model and Estimated Data Panel Regression Methods}

The selection of estimation models is done using the Chou test (Chou-test), Hausman test, and Lagrange Multiplier test. The Chou test results show a probability of more than 0.05 . The chi square test value is 4.26 . This value is lower than the chi square table with 18 degrees of freedom which is equal to 28.87. This is shows that the common effect model is better than the fixed effect model.

The Hausman test results show a probability of more than 0.05 . The chi square test value is 2.90 . This value is lower when compared with the chi square table with 4 free degrees which is equal to 9.49. This is shows that the random effect model is better than the fixed effect model. 
The Lagrange Multiplier test results show a Breusch-Pagan test value with p-value less than 0.05 . This shows that the random effect model is better than the common effect model. In this study, the estimation model that can be used is the Random effects model.

\section{Classic assumption test}

According to Gujarati \& Porter (2009), the assumption test in the random effects model is no longer needed, as we know random estimation is Generalized Least Square (GLS) which involves the structure of covariance variance in the estimation process, so that it is generalized.

\section{Estimated Results}

After the model selection test is carried out, the random effects model is used to analyze the influence of economic growth, health, education, and government expenditure on infrastructure towards inclusive growth that reduces inequality in West Sumatra. The results of the equation estimation are as presented in Table 2.

Table 2 Output of Random Effect Model Panel Data Regression

\begin{tabular}{lrrrr}
\hline \multicolumn{1}{c}{ Variable } & Coefficient & \multicolumn{1}{c}{ Std. Error } & t-Stat & \multicolumn{1}{c}{ Prob. } \\
\hline $\mathrm{C}$ & -0.3301 & 0.7231 & -0.4565 & 0.6491 \\
\hline $\mathrm{D}$ (InGRDP) & 6.4452 & 12.6053 & 0.5113 & 0.6104 \\
\hline $\mathrm{D}$ (HEALTH) & 0.0105 & 0.0062 & 1.7031 & 0.0092 \\
\hline $\mathrm{D}$ (EDU) & 4.9117 & 1.2139 & 4.0462 & 0.0001 \\
\hline $\mathrm{D}$ (InINF) & -0.3492 & 0.1431 & -2.4413 & 0.0166 \\
\hline
\end{tabular}

Source: Own calculations using data from BPS 2011-2016 data sets

$\begin{array}{llll}\text { F test } & =10,17 & \text { Adj } R^{2} & =0,28 \\ \text { F table } & =2,50 & \alpha & =0,05 \\ \mathrm{R}^{2} & =0,31 & \mathrm{~N} & =95\end{array}$

In summary, the estimation model of inclusive growth in West Sumatra in the 2011-2016 period can be written as follows:

$\Delta($ IGin $)=-0,3301+0,64452 \Delta(\ln$ PDRB $)+0,0105 \Delta($ KES $)+4,9117 \Delta($ PEND) $-0,3492 \Delta(\operatorname{lnINF})$

The four independent variables used in this study are economic growth, health, education, and government expenditure for infrastructure simultaneously (simultaneous) influencing the growth of inclusive inequality in West Sumatra.

The R-Squared value obtained in the model is 0.3112 , which means that all the independent variables in this study are able to explain the proportion of variance of the dependent variable by 31.12 percent, while the remaining 68.88 percent is explained by other variables outside the model.

If viewed partially, the explanatory variables used as indicators namely health have a positive and significant effect at the five percent significance level, while education has a positive and significant effect on the 10 percent significance level. Government expenditure on infrastructure has a negative and significant influence at the five percent significance level, while economic growth has no statistically significant effect.

The parameter estimation results in the model presented in Table 2 show that health has a significant and positive effect on increasing inclusive growth in West Sumatra at a 10 percent significance level. This means that each increase in the percentage of population with sufficient nutrition by one percent causes an increase in inclusive growth of 0.0105 units during the condition of ceteris paribus. This means that the more people who have enough nutrition in an area, the more the area will increase the opportunities to achieve inclusive growth in inequality.

The parameter estimation results in the model presented in Table 2 show that education has a significant and positive effect on the increase in inclusive vegetation in West Sumatra at a 5 percent significance level. This means that each increase in the change in the mean years school by one year causes an increase in inclusive growth of 4.9117 units during the condition of ceteris paribus. This 
means that the higher the quality of education of the people in an area, the more the area will increase the opportunities to achieve inclusive growth towards inequality.

The parameter estimation results in the model presented in Table 2 show that government spending on infrastructure has a negative and significant and positive effect on the decline in inclusive growth in West Sumatra at a 5 percent significance level. This means that each one percent increase in government expenditure growth for infrastructure causes a decline in inclusive growth of 0.3492 units when the condition of ceteris paribus.

\section{Effects of Economic Growth on Inclusive Growth on Inequality in West Sumatra}

From the results of the tests that have been conducted, it can be concluded that economic growth does not have a significant effect on inclusive growth. This indicates that economic growth still has little effect on the poor. In addition, even though economic growth is at a moderate level, every year there is always a slowdown.

The primary sector includes agriculture, livestock, forestry and fisheries. This sector is the sector that absorbs the most labor in West Sumatra. About 39 percent of the workforce in West Sumatra is absorbed by this sector. This is in line with the sector's share of the economy. In 2011 this sector's share of the economy was 25.74 percent. This share continues to experience a decline to the lowest point in 2016 at 24.02 percent. In addition, the sector which is the place to depend on the majority of the population of West Sumatra, the smaller the growth and contribution to the economy. If this is allowed, the longer the poor will not benefit from economic growth.

Data shows that economic growth in West Sumatra during 2011 to 2016 was above five percent. This shows that economic growth in West Sumatra is in the moderate category. This economic growth must always be supported by sectors that can absorb labor, so that economic growth will be felt by all levels of society.

This result is in line with the opinion of some economists, namely that economic growth alone is not enough to solve the problem of poverty and economic inequality. This is because economic growth generally only emphasizes the growth of a country's Gross Domestic Product but does not pay attention to the problem of poverty reduction, income distribution and employment. As a result, the economic growth that occurred actually increased the number of poor people and widened income inequality between individuals. Measuring the results of development only from economic growth alone will eliminate the occurrence of equity in society to enjoy the results of development (Maskin, 1999).

Then the results of research by BPS \& BAPPEDA (2016) concluded that when high economic growth has been achieved, it turns out the problems of poverty, unemployment and income inequality cannot necessarily be resolved. A small decrease in the number of poor people, a reduction in the unemployment rate is limited, even income inequality in society is widening. This condition causes the quality of economic growth to be questioned.

\section{Health Effects of Inclusive Growth on Inequality in West Sumatra}

The health indicator used is the percentage of the population who have enough nutrition. The population is said to be undernourished when consuming calories as much as 2,150 kcal/capita/day and protein as much as $57 \mathrm{gr} / \mathrm{capita} /$ day, Standard Minister of Health Regulation no. 75 of 2013 concerning the minimum number of nutritional adequacy is $2,150 \mathrm{kcal}$ and 57 grams of protein.

The parameter estimation results in the model presented in Table 2 show that health has a significant and positive effect on the incremental growth of inclusive inequality in West Sumatra at a 10 percent significance level. This indicates that health is something that needs to be improved to achieve inclusive growth. Improvement in health will improve the quality of human resources. Healthy human resources can carry out economic activities well without being disturbed by disease problems, so that the time to work and activities will be used effectively and efficiently. This will increase productivity. With the increase in product this will increase output. This increase in output 
will spur economic growth, thus achieving inclusive economic growth. So it can be concluded that by increasing the degree of public health it will result in inclusive growth in inequality.

Positive and significant health effects on inclusive growth in West Sumatra are in line with the report of the Asian Development Bank (2017) which concludes that investment in the health sector contributes to inclusive growth. Ikhide (2016) suggests that there is a need to focus attention on health problems. This is because in the long run the outcomes of long-term health investments will have a good impact on inclusive growth, especially for developing countries.

\section{The Effect of Education on Inclusive Growth on Inequality in West Sumatra}

The education indicator used is the mean years school (MYS). This indicator is used to see the quality of the population in terms of formal education. The parameter estimation results in the model presented in Table 2 show that education has a significant and positive influence on increasing inclusive growth inequality in West Sumatra.

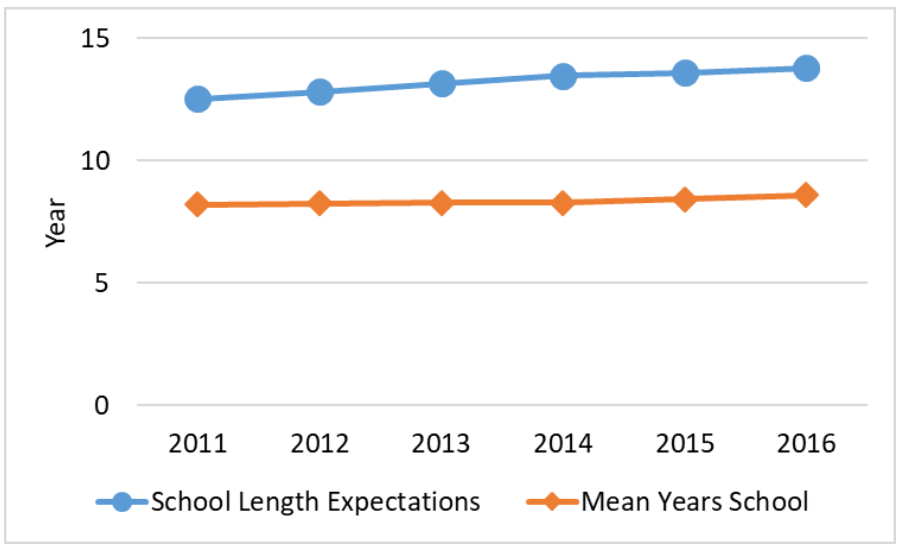

Source: Badan Pusat Statistik

Figure 3 School Length Expectations and Mean Years School in West Sumatra, 2011-2016

Figure 3 shows the old school expectations (HLS) and the mean years school (MYS) of residents in West Sumatra in 2011 to 2016. The MYS of the population of West Sumatra is consistently increasing every year. This shows that the quality of education in West Sumatra always increases every year. West Sumatra's MYS in 2011 amounted to 8.2. This means that on average, the level of education pursued by residents in West Sumatra up to grades 2-3 in junior high school. Then this value continues to increase until in 2016 it becomes 8.59 years. This increase in MYS is offset by an increase in the HLS. HLS can be used to determine the condition of the education system development at various levels. HLS West Sumatra in 2011 amounted to 12.52 years. This means that on average 7year-olds who enter formal education in 2011 have the opportunity to attend 12.52 years of school or equivalent to Diploma I. Then this value continues to increase to become 13.79 in 2016. Seeing West Sumatra has high potential in the field of education, and the results of panel data analysis also have a high coefficient, so this education should be a top priority for achieving inclusive growth.

The positive and significant influence of education on inclusive growth in West Sumatra is in line with Dinda (2014); OECD (2017) concludes that human capital and social capital are important for achieving inclusive growth. The results of this study suggest that the need for policies is mainly related to improving the quality of education in order to achieve inclusive growth. Then (Paik, 2015) also concluded the same thing, that for the achievement of inclusive growth that is with development in the field of education.

\section{Effects of Government Expenditures on Inclusive Growth in Inequality in West Sumatra}

The government has an important role as a stakeholder. Policies that are right on target and relevant will spur the economy. The model estimation results in Table 2 show that the coefficient of government expenditure for infrastructure is positive but not significant. This shows that government 
expenditure on infrastructure does not significantly affect inclusive growth in poverty, inequality and unemployment.

In addition, large-scale infrastructure development has various impacts. Improper infrastructure development has the potential to widen the gap through rising property prices. This will be a burden to the public. Before there was infrastructure development, the prices of houses and land were already high. Data shows that the average annual inflation rate for housing components is 4.66 percent. In addition, the highest percentage of the average per capita expenditure after the food subcomponent is the sub-component of housing expenditure and household facilities. This share in 2016 reached 20.94 percent. This share increased when compared to 2011 which amounted to 15.20 percent. This means that the portion of people's income is increasingly used only for housing so it must reduce other income posts. Data shows that share of population expenditure for food always decreases. In 2011 the share of food expenditure was 56.77 percent. This share declined in 2016 to 54.54 percent.

Not only that, it is necessary to have good regulations and institutional arrangements to achieve inclusiveness. According to the Economist of the Institute for Development of Economics and Finance (INDEF) Bima Yudhistira in KOMPAS (2018), stated that the construction of infrastructure built by the government is currently deviating from its original objectives. This is due to the large number of State-Owned Enterprises (BUMN) that are required to be involved in infrastructure construction but are not prepared in detail and mature.

\section{Conclusions}

Inclusive growth in West Sumatra only occurred in 2014. In 2014 it was also the region with the most inclusive growth, namely as many as 12 regions. In 2013 none of the regions had inclusive growth. The areas with the most inclusive growth are Mentawai Islands regency, West Pasaman district, and Padang city.

Economic growth has a positive influence on inclusive growth. Therefore, economic growth must be increased. However, during the 2011-2016 period, inclusive growth in West Sumatra only occurred in 2014. This shows that existing economic growth should not only focus on increasing output, but also on how the quality of growth itself. The government must provide regulatory support and investment in the economic sector that absorbs a lot of labor.

Health has a positive influence on inclusive growth. Therefore, the level of public health must be increased. Based on data, there are still many people who have not had enough nutrition. Therefore, the government is expected to provide counseling to the public about healthy eating patterns, healthy lifestyles, and assistance for the poor to fulfill their nutrition. This is needed, seeing that there are some regions that actually experience a decline in the percentage of the population who have enough nutrition. In addition, health workers still need to be improved. At present the condition of the ratio of health workers compared to 100,000 residents in West Sumatra is still lacking.

Education has a positive influence on inclusive growth. Therefore, the government must be able to reduce the dropout rate. This policy can be done by providing assistance to the poor and vulnerable to poverty. In addition, the availability of educational facilities needs to be improved. The current condition of educational buildings is still quite large which is lightly to heavily damaged. In addition, the distribution of teaching staff needs to be considered, so that the ratio of teachers to students will be balanced.

\section{References}

ADB (2012) Infrastructure for Supporting Inclusive Growth and Poverty Reduction in Asia, Asia Development Bank, Manila, Philippines.

Ali, I. and Son, H. H. (2007) "Measuring Inclusive Growth," Asian Development Review. 24th ed. Edited by I. Ali and C. L. T. Zafaralla. Manila: Asian Development Bank, 24(1), pp. 11-31.

Asian Development Bank (ADB) (2017) "Promoting Inclusive Growth through Health Development in Central and West," (February). 
Badan Pusat Statitik Provinsi DIY and BAPPEDA DIY (2016) Analisis Pertumbuhan Ekonomi Inklusif Daerah Istimewa Yogyakarta 2011-2015. Yogyakarta: Badan Perencanaan Pembangunan Daerah Badan Pusat Statistik Provinsi Daerah Istimewa Yogyakarta.

Dinda, S. (2014) "Inclusive Growth Through Creation of Human and Social Capital," International Journal of Social Economics, 41(10), pp. 878-895. doi: 10.1108/IJSE-07-2013-0157.

Ganesh Rauniyar; Ravi Kanbur (2010) Inclusive Development : Two Papers on Working Paper. New York.

Gujarati and Porter (2009) Dasar-Dasar Ekonometrika. Jakarta: Salemba Empat.

Ikhide, S. I. (2016) "Inclusive Growth, Healthy Aid and Health Outcomes in Africa," International Journal of Sustainable Development, 19(4), pp. 383-401. doi: 10.1504/IJSD.2016.080513.

Klasen, S. (2010) Measuring and Monitoring Inclusive Growth: Multiple Definitions, Open Questions, and Some Constructive Proposals. Manila.

KOMPAS (2018) INDEF: Pembangunan Infrastruktur Melenceng dari Tujuan Awal. Available at: https://ekonomi.kompas.com/read/2018/05/13/173612626/indef-pembangunan-infrastrukturmelenceng-dari-tujuan-awal (Accessed: November 11, 2018).

Lee, N. and Sissons, P. (2016) "Inclusive Growth? The Relationship between Economic Growth and Poverty in British Cities," Environment and Planning A, 48(11), pp. 2317-2339. doi: $10.1177 / 0308518 \times 16656000$.

Maskin, E. (1999) “Nash Equilibrium and Welfare Optimally,” Review of Economic Studies, (66), pp. 2338.

OECD (2017) Bridging the Gap: Inclusive Growth 2017 Update Report. Paris.

Paik, S. J. (2015) "Education and Inclusive Growth - Korean Experience," Ssrn. doi: $10.2139 /$ ssrn.2700644.

Permenkes (2013) “Permenkes No 75 Tahun 2013."

Sen, K. (2014) "Inclusive Growth: When May We Expect it? When May We Not?," Asian Development Review, 31(1), pp. 136-162. doi: 10.1162/ADEV_a_00022.

Syamsul, A. et al. (2017) Kajian Pembangunan dalam Perspektif Empiris. Padang: Sukabina Press. 